\title{
THE ROLE OF MARKETING MIX AND SERVICE QUALITY ON TOURIST SATISFACTION AND LOYALTY AT SAMOSIR
}

Muhammad Elfi Azhar Faculty of Economics and Business, University of Muhammadiyah Sumatera Utara, Indonesia

E-mail: mayasariumsu@gmail.com

Jufrizen Jufrizen Faculty of Economics and Business, University of Muhammadiyah Sumatera Utara, Indonesia

E-mail: jufrizen@umsu.ac.id

Muhammad Andi Prayogi Faculty of Economics and Business, University of Muhammadiyah Sumatera Utara, Indonesia

E-mail: mayasariumsu@gmail.com

Maya Sari Faculty of Economics and Business, University of Muhammadiyah Sumatera Utara, Indonesia

E-mail: mayasari@umsu.ac.id

Submission: 12/15/2018

Revision: 12/19/2018

Accept: 1/05/2019

\section{ABSTRACT}

This study aims to investigate the effect of the marketing mix and service quality on tourist satisfaction and loyalty. The data collection techniques used in this study included interviews and questionnaires to the relevant parties. The technique of data analysis in this study was descriptive and Structural Equation Modelling (SEM). The results showed that the marketing mix had a positive and significant effect on tourist's satisfaction. The service quality had a positive and significant effect on tourist's satisfaction in the region of Samosir. Marketing mix had a positive and significant effect on tourist's loyalty. The service quality had a positive and significant effect on tourist's loyalty. Tourist satisfaction had a positive and significant effect on tourist's loyalty in the region of Samosir. And the marketing mix and the service quality had a significant effect on tourists in the Samosir Region through tourist satisfaction. 
INDEPENDENT JOURNAL OF MANAGEMENT \& PRODUCTION (IJM\&P)

http://www.ijmp.jor.br

V. 10, n. 5, September-October 2019

ISSN: 2236-269X

DOI: 10.14807/ijmp.v10i5.937

It also revealed that employees of lower age and longer experience are preferable because of shorter operating times and that the age was statistically significant, revealing that the most appropriate age to have a shorter time is approximately 27 years.

Keywords: Marketing Mix, Service Quality, Satisfaction, Loyalty, Tourists

\section{INTRODUCTION}

Samosir is one of the largest lake in the world, and the largest and most popular in Indonesia. Samosir is located in North Sumatra area which is one of the valuable assets in the State/Local Government and is one of the important tourist destination after Bali and Lombok, so it is a pride for the region. The establishment of Samosir as one of the tourist destination, because the assumption of beautiful natural panorama (SIANTURI, 2004).

However, Samosir tourism activities are currently not experiencing developments, as seen from a decrease in the number of visitors so that tourism facilities are starting to be neglected (BUATON; PURWADIO, 2015). In Samosir tourism area, there are not only Samosir tourism object but also 4 other tourism objects, namely Batu Gantung, Kera Huta Sibatu Loting Tourism Park, Bangun Dolok and camping ground and also Dolok Simarbalatuk. These objects are in fact if developed properly can provide more value in Parapat tourism area, but the current conditions of these objects are almost unknown to the public (BUATON; PURWADIO, 2015).

To manage the tourism industry properly and profesionally, an in-depth study is needed including tourists as the source of income that must be served well to keep them happy and comfortable so that the residence time within the tours area will be longer. The tourism industry is a type of product which is mostly engaged in the service, for all aspects related to the economic orientation are services (HIDAYAT, 2010).

The dynamics that occur in the tourism services sector can be seen from the development of various industries such as banking, insurance, telecommunications and others. Marketing services intended to build expectations of tourists and make a promise to the tourist (DARYANTO, 2013). 
INDEPENDENT JOURNAL OF MANAGEMENT \& PRODUCTION (IJM\&P)

http://Www.ijmp.jor.br

V. 10, n. 5, September-October 2019

ISSN: 2236-269X

DOI: 10.14807/ijmp.v10i5.937

The company strives to meet the expectations and promises to tourists so that tourists are satisfied. Consumer satisfaction is the level of one's feelings after comparing performance (results) that perceived with the expectation (Daryanto, 2013). Tourists experiencing various levels of satisfaction or dissatisfaction after experiencing each services in accordance with the extent to consumer expectations are met or exceeded.

This is because satisfaction is the emotional state, the post-purchase reaction of tourists can be anger, dissatisfaction, irritation, neutrality, joy, or pleasure. Tourists who are angry or dissatisfied would cause problems because they can be moved to another company and spread the negative word of mouth (LOVELOCK; WRIGHT, 2007).

Many factors can affect tourist loyalty, including the marketing mix and service quality. It is supported by some research results of Azhar and Jufrizen (2017), and Gultom (2017), Setiawan and Sayuti (2017), Tefera and Govender (2017) stating that the service quality and marketing mix has a positive and significant effect on tourist loyalty. This studywas made aiming to replicate the study, because of the marketing mix and service quality effect on tourist loyalty.

This study was made aiming to replicate the study, because of the marketing mix and service quality affects the tourist satisfaction and loyalty. So the played purpose of the study is divided into six sub-goals:

a) To Investigate the impact of the marketing mix on tourist satisfaction.

b) To investigate the impact of service quality on tourist satisfaction.

c) To Investigate the impact of the marketing mix on tourist loyalty.

d) To investigate the impact of service quality on tourist loyalty.

e) To investigate the impact of the tourist satisfaction on tourist loyalty.

f) To Investigate the Mediation Role of Tourist Satisfaction on the Effect of Marketing Mix and Service Quality on Tourist Loyalty.

\section{LITERATURE REVIEW}

\subsection{Loyalty}

Loyalty is the willingness of tourists to continue the purchase on a company in a long period of time and use the product or service repeatedly, as well as recommend 
INDEPENDENT JOURNAL OF MANAGEMENT \& PRODUCTION (IJM\&P)

http://Www.ijmp.jor.br

V. 10, n. 5, September-October 2019

ISSN: 2236-269X

DOI: 10.14807/ijmp.v10i5.937

it to friends and other companies in voluntary (OLIVER, 2002). While according to Griffin (2005) consumer loyalty is a concept of loyalty that leads more to behaviour than attitude and a loyal consumer will show a purchase behavior which is defined as a regular purchaser and shown over times by some decision making units. Loyalty is important concept in marketing because loyalty is one of the factors to be able to determine the market share of a company.

Consumer loyalty is a behavioral drive to make purchases repeatedly and to build consumer loyalty to a product/service that is produced by a company that takes a long time through a repetitive purchasing process (OLSON, 1993).

Loyalty does not only mean the existence of consumer wishes to buy back the same brand in later time, but also the consumer have a psychological commitment or attitude towards the brand. And the loyal tourists are not only buy the brand but also refused to switch to other brands even though other brands offer something more than the brands they use (WELLS et al. 2003).

Loyal onsumers are not sensitive to price, deliver a positive recommendation regarding the brand and willing to spend more money on these brand-producing company (UNCLES, et al., 2003). Loyalty can also refers to the preference of tourists to purchase a particular brand of a product category. This occurs because tourists feel that a brand is able to offer the product features, product image or product quality level which matches to the price. Basically, the first time tourists will experiment in the purchase of a product, after they try the product and feel satisfied, they will make it a habit and will continue to purchase the same product because they feel the product is more secure and known (GIDDENS, 2002).

\subsection{Consumer Satisfaction}

Johnson and Fornell (1991) stated that consumer satisfaction is the result of a thorough evaluation of the top performing consumer products which they consume. Yi (1991) identified two different concepts of customer satisfaction, namely transactionspecific satisfaction and overall satisfaction. Transaction-specific satisfaction is a concept that refers to the assessment of customer satisfaction after purchasing particular products or brands.

While overall satisfaction is a concept that measures the satisfaction (dissatisfaction) of tourists towards particular products or brands as a whole based on 
INDEPENDENT JOURNAL OF MANAGEMENT \& PRODUCTION (IJM\&P)

http://Www.ijmp.jor.br

V. 10, n. 5, September-October 2019

ISSN: 2236-269X

DOI: 10.14807/ijmp.v10i5.937

the entire experience in consuming these products or brands. Thus overall satisfaction could be viewed as a function of all transaction-specific satisfaction that occurred before. In this study, the concept of customer satisfaction that used is overall customer satisfaction. By knowing the measurement results in consumer satisfaction, the company can prepare strategies that will be implemented in order to create consumer loyalty (HADIYATI, 2012).

Consumer satisfaction according to Kotler and Armstrong (2009) is the level of consumer feelings after comparing performance (or results) that the consumer perceive than their expectations. According to Hasan (2009) consumer satisfaction is a feeling of consumer in good response of products or services that has been consumed. In general satisfaction can be defined as a comparison between results received or services in consumer expectations, results received or services at least must be equal with consumer expectations, or even beyond it.

Kotler (2009) revealed that satisfaction is as feelings of like or dislike someone for a product after he/she compared a product performance with his/her expectations. Simamora (2008) argues that customer satisfaction is the result of experience in the product. This is a consumer feeling after compare between expectations (prepurchase expectation) and actual performance.

\subsection{Marketing Mix}

Marketing mix is the set of controlled tactical marketing tools (products, prices, places and promotions) that combined company to produce the desired response in the target markets (KOTLER; ARMSTRONG, 2009).

Daryanto (2013), the marketing mix is the tactical marketing tools that can controlled and combined by the company to produce the desired response in the target markets. Marketing mix is the variables to be monitored by the company to satisfy the groups targeted (CANNON, et al, 2008).

Marketing mix consists of a product, is offered at a certain price, with some kind of promotion to tell prospective tourists about these products, and a way to reach consumer's place (CANNON, et al, 2008). Marketing mix consists of all the things that a company can do to influence the demand for its products (KOTLER; ARMSTRONG, 2009). 
Effective marketing program combines all the elements of the marketing mix into an integrated marketing program designed to achieve the company's marketing goals by delivering value for tourists. Marketing mix is the company's tactical advice to determine a strong positioning in the target markets (KOTLER; ARMSTRONG, 2009).

\subsection{Service Quality}

Service quality is the evaluation of tourists' long-term observationsin the service delivery of a company (LOVELOCK; WRIGHT, 2007). The definition of service quality is the magnitude of the difference between expectations or desires of tourists with their level perception (LAKSANA, 2008).

According to Kotler and Keller (2009), service quality is a statement about the attitude towards the comparison between expectations and performances. Meanwhile, according to Lovelock, et al (2011), service quality is something that consistently meet or exceed consumer expectations.

Also according to Ratnasari and Aksa (2011), service quality is how far the difference between reality and consumer expectations for services received/retrieved. While the Yamit (2010) stated that in general, service quality can be seen from the comparison between consumer expectations andservice performances.

The best service to customers and the level of quality can be achieved consistently by improving services and paying special attention to good service standard performance both in internal service standard or external service standard. Before the consumer buys a service, tourists have expectations about the service quality that is based on personal needs, experiences, word of mouth recommendations, and ad service providers. After buying and using these services, tourists compare the expected quality with what is truly received (LOVELOCK; WRIGHT, 2007).

\section{RESEARCH METHODS}

The location of the study was carried out in the tourism destinations of Samosir Region, North Sumatra, located in seven districts namely Simalungun Regency, Toba Samosir Regency, Samosir Regency, North Tapanuli Regency, Humbang Hasundutan Regency, Karo Regency, Dairi Regency. The population in this study were all tourists who visiting the Samosir Region. 
INDEPENDENT JOURNAL OF MANAGEMENT \& PRODUCTION (IJM\&P)

http://Www.ijmp.jor.br

V. 10, n. 5, September-October 2019

ISSN: 2236-269X

DOI: 10.14807/ijmp.v10i5.937

The sample used non probability sampling, allowing the opportunity for someone to be a respondent was not known. Sampling of tourists in this study was determined by quota sampling as many as 200 respondents either male or female. In this study, the sampling technique was accidental sampling, which was how to obtain samples based on tourists who was found when conducting the study, which was taken from the research site without distinguishing the origin of the tourists.

Data collection techniques used in this study includes interviews and questionnaires to the relevant parties. In its implementation, researchers get respondents by visiting respondents one by one, then asking their willingness to become respondents in this study, after the respondents are willing, the authors interview respondents one by one based on the prepared questionnaire.

The interview was carried out in the morning until noon when the visitors arrived. Before the questionnaire was distributed, validity and reliability tests were carried out first.. The technique of data analysis in this study is descriptive and Structural Equation Modelling (SEM)

\section{RESULTS}

\subsection{Structural Model Analysis}

After calculating and analyzing the Confirmatory Factor Analysis (CFA), it can be measured latent score for each latent variables. Analysis of the structural model includes several things, namely:

- Overall Model Match Test

Table 1: Goodness of Fit Structural Equation Model (SEM)

\begin{tabular}{|l|l|l|}
\hline Ukuran GoF & Nilai & $\begin{array}{l}\text { Tingkat } \\
\text { Kecocokan }\end{array}$ \\
\hline $\begin{array}{l}\text { Statistic Chi Square ( } \square \text { ) } \\
\text { Goodness of Fit Index (GFI) }\end{array}$ & 383,47 & Not Fit \\
\hline $\begin{array}{l}\text { Standardized Root Mean Square Residuan } \\
\text { (SRMR) }\end{array}$ & 0.84 & Marginal Fit \\
\hline $\begin{array}{l}\text { Root Mean Square Error of } \\
\text { Approximation (RMSEA) }\end{array}$ & 0.073 & Marginal Fit \\
\hline Non-Normed Fit Index (NNFI) & 0.066 & Good Fit \\
\hline Normed Fit Index (NFI) & 0.95 & Good Fit \\
\hline Adjusted Goodness of Fit Index (AGFI) & 0.91 & Good Fit \\
\hline Relative Fit Index (RFI) & 0.80 & Marginal Fit \\
\hline
\end{tabular}


DOI: 10.14807/ijmp.v10i5.937

\begin{tabular}{|l|l|l|}
\hline Incremental Fit Index (IFI) & 0.96 & Good Fit \\
\hline Comparative Fit Index (CFI) & 0.96 & Good Fit \\
\hline
\end{tabular}

Source: LISREL Output of 8.80 Processed Results of Researcher

In table 1 above we can see the GFI value of 0.84 and AGFI of 0.80 and SRMR of 0.073 which fall into the marginal fit category. The value of RMSEA, NFI, and RFI $\mathrm{NNFI}, \mathrm{IFI}$, and CFI, itall fall into the good fit category. So it can be concluded that the overall fit of the model is already good.

\subsection{Causal Relationships Analysis}

After analyzing the result of goodness of fit research model, the next analysisis to do an analysis of the causal relationships in the model. Statistical testing for causal relationships of structural model is made with a significance level of $5 \%$ so that critical value from $\mathrm{t}$-value is \pm 1.96 . The estimation results of all causal relationships of the study can be seen in the results.

The following LISREL 8.80 output:

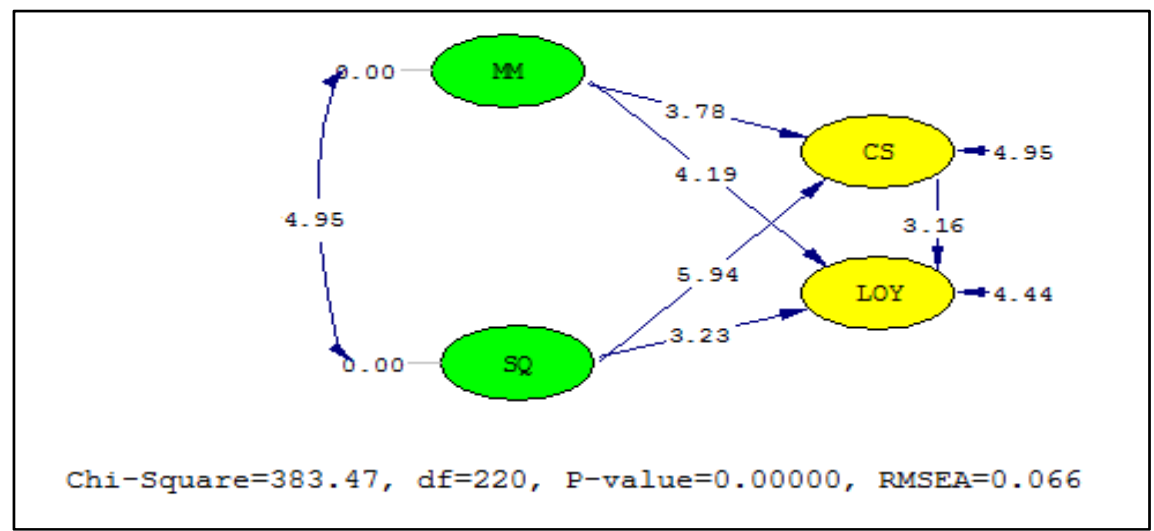

Figure 2: Structural Models (tvalues)

\subsection{Hypothesis Testing}

As explained in the previous chapter, there are 5 hypotheses in this study. Hypothesis testing analysis is carried out with a significance level of $5 \%$, resulting in a critical $t$-value of \pm 1.96 . The hypothesis is accepted if the $t$-value obtained $\geq 1.96$, while hypothesis is not supported if the t-value obtained $<1.96$. The following is a table of hypothesis testing to answer the overall questions of the study:

Table 2: Hypothesis Testing of Research Model

\begin{tabular}{|l|lll|l|l|l}
\hline Hypothesis & Statements & & T-value & Notes \\
$\mathrm{H}_{1}$ & $\begin{array}{l}\text { Marketing Mix on Tourist } \\
\text { Satisfactions }\end{array}$ & 3,78 & $\begin{array}{l}\text { Data } \\
\text { Hypothesis }\end{array}$ & SupportingThe \\
\end{tabular}


INDEPENDENT JOURNAL OF MANAGEMENT \& PRODUCTION (IJM\&P)

http://www.ijmp.jor.br

v. 10, n. 5, September-October 2019

ISSN: 2236-269X

DOI: 10.14807/ijmp.v10i5.937

\begin{tabular}{|c|c|c|c|c|}
\hline $\mathrm{H}_{2}$ & $\begin{array}{l}\text { Quality Service on Tourist } \\
\text { Satisfactions }\end{array}$ & 5,94 & $\begin{array}{l}\text { Data } \\
\text { Hypothesis }\end{array}$ & SupportingThe \\
\hline $\mathrm{H}_{3}$ & Marketing Mix on Tourists Loyalty & 4,19 & $\begin{array}{l}\text { Data } \\
\text { Hypothesis }\end{array}$ & SupportingThe \\
\hline $\mathrm{H}_{4}$ & Quality Service on Tourists Loyalty & 3,23 & $\begin{array}{l}\text { Data } \\
\text { Hypothesis }\end{array}$ & SupportingThe \\
\hline $\mathrm{H}_{5}$ & $\begin{array}{l}\text { Tourist Satisfactions on Tourists } \\
\text { Loyalty }\end{array}$ & 3,16 & $\begin{array}{l}\text { Data } \\
\text { Hypothesis }\end{array}$ & SupportingThe \\
\hline
\end{tabular}

Based on table 2 above which contains the conclusion of the hypothesis model results, it can be concluded as follows:

\section{a) Marketing Mix has a positive effect on Tourist Satisfactions}

Based on data processing results of structural model, the output of t-value is 3.78. The result of t-value shown is greater than 1.96 , then it can be concluded that the variable of marketing mix has a positive effect on tourist satisfactions significantly. Thus, the hypothesis 1 can be accepted and it can be concluded that the higher marketing mix perceived, then it will be higher tourist satisfactions.

b) Service Quality has a positive effect on Tourist Satisfactions

Based on data processing results of structural model, the output of $t$-value is 5.94. The result oft-value shown is greater than 1.96 , then it can be concluded that the variable of service qualityhas a positive effect on tourist satisfactions significantly. Thus, it can be concluded that the higher marketing mix perceived, then it will be higher tourist satisfactions.

\section{c) Marketing Mix has a positive effect on Tourists Loyality}

Based on data processing results of structural model, the output of $t$-value is 4.19. The result oft-value shown is greater than 1.96, then it can be concluded thatthe variable of marketing mixhas a positive effect ontourists loyalty significantly. Thus, it can be concluded that the higher marketing mix perceived, then it will be higher tourist's loyalty.

\section{d) Service Quality has a positive effect on Tourists Loyalty}

Based on data processing results of structural model, the output of $t$-value is 3.23. The result oft-value shown is greater than 1.96, then it can be concluded thatthe variable of service qualityhas a positive effect ontourists loyalty significantly. Thus, it can be concluded that the higher service quality perceived, then it will be higher tourists loyalty. 


\section{e) Satisfactions has a positive effect onTourists Loyalty}

Based on data processing results of structural model, the output of $t$-value is 3.16. The result oft-value shown is greater than 1.96, then it can be concluded thatthe variable of satisfactions has a positive effect ontourists loyalty significantly. Thus, it can be concluded that the higher satisfactions perceived, then it will be higher tourists loyalty.

\section{- Hypothesis Testing Of Mediation (Indirect Effects)}

As explained in the previous chapter, in this study there are two moderation hypotheses by Tourist Satisfaction variables. Hypothesis testing analysis is carried out with a significance level of $5 \%$, resulting in a critical t-value of \pm 1.96 . The hypothesis is accepted if the $t$-value obtained $\geq 1.96$, while hypothesis is not supported if the $t$ value obtained $<1.96$.

The following is a table of testing hypotheses to answer indirect influences.

Table 3. Testing of Indirect Influence Hypotheses

\begin{tabular}{|l|c|}
\hline \multicolumn{1}{|c|}{ Hypothesis } & Through \\
\hline \multicolumn{1}{|c|}{ Indirect Effects (tcount) } & Tourist Satisfaction \\
\hline Effect of Marketing Mix on Loyalty & 2.50 \\
\hline Effect of Service Quality on Loyalty & 3.00 \\
\hline
\end{tabular}

Source: LISREL Output 8.80 Processed Researchers

Based on the results of the LISREL output above, the data from the structural model, obtained the output of t-value (line 3 ), in the result showed that the variables of tourists satisfaction can mediate the effect between the variable of marketing mix and service quality that has an indirect effect on tourists loyalty. This can be seen from $\mathrm{t}$-count value is greater than 1.96 i.e. 2.50 and 3.00 .

\section{DISCUSSION}

Based on the results of factor analysis that has been presented in the previous chapter obtained that the variable which effect on tourists loyalty of Samosir Region in this study is the marketing mix, service quality and tourist satisfactions. The following is the linkages between variables, namely:

\section{a) Marketing Mix Effects on Tourist Satisfactions}


INDEPENDENT JOURNAL OF MANAGEMENT \& PRODUCTION (IJM\&P)

http://Www.ijmp.jor.br

V. 10, n. 5, September-October 2019

ISSN: 2236-269X

DOI: 10.14807/ijmp.v10i5.937

Based on the results of the study showed that marketing mix has a positive and significant effect on tourist satisfactions in Samosir Region. The results of this study means that if the better implementation of marketing mix, it will increase tourist satisfactions. Conversely, if the weak implementation of marketing mix, the tourists will be dissatisfied.

According to Oliver (2002) loyalty is the commitment of customers to stay in depth to re-subscribe or re-purchase selected products or services consistently in the future, even though the influence of the situation and marketing efforts has the potential to cause behavior change. Empirically, the findings of this study supporting the study that was conducted by Rasyid et al., (2017), Teviana et al. (2017), Ismail et al. (2015) and Gultom (2017) which showed that marketing mix had an effect on tourist satisfactions. Meanwhile, the results of the study by Al Muala and AI Qurneh (2012) concluded that products had a significant effect on tourist satisfactions, while prices, people and processes had no significant effect on tourist satisfactions. The results of the study by Megatef (2015) concluded that all elements of the marketing mix had a very strong effect on tourist satisfactions.

\section{b) Service Quality Effects on Tourist Satisfactions}

Based on the results of the study showed that service quality has a positive and significant effect on tourist satisfactions in Samosir Region. The results of this study means that if the better implementation of service quality, it will increase tourist satisfactions. Conversely, if the weak implementation of service quality, the tourists will be dissatisfied.

A successful marketing program can be seen from its ability to satisfy the wants and needs of consumers. The combination of marketing mix elements was created to be able to meet customer satisfaction together. Previous research shows a variety of findings where not all marketing mix elements always affect satisfaction.

Empirically, the findings of this study supporting the study that was conducted by Rasyid et al., (2017) concluded that service quality had a significant effect on tourist satisfactions. The results of this study also reinforce the results of previous study conducted by Setiawan and Sayuti (2017), Adinegara et al. (2017), Tefera \& Govender (2017) who concluded that service quality had an effect on tourist satisfactions. 
INDEPENDENT JOURNAL OF MANAGEMENT \& PRODUCTION (IJM\&P)

http://Www.ijmp.jor.br

V. 10, n. 5, September-October 2019

ISSN: 2236-269X

DOI: 10.14807/ijmp.v10i5.937

\section{c) Marketing Mix Effects on Tourists Loyalty}

Based on the results of the study showed that marketing mix has a positive and significant effect on tourists loyalty in Samosir Region. The results of this study means that if the better implementation of marketing mix, it will increase tourists loyalty. Conversely, if the weak implementation of marketing mix, the tourists will be not loyalGriffin (2005) stated his opinion about consumer loyalty is a concept of loyalty more towards behavior (behavior) compared to attitude (attitude) and a loyal consumer will show purchasing behavior that is defined as regular buyers and shown all the time by several decision-making units.

Empirically, the findings of this study supporting the study that was conducted by Azhar and Jufrizen (2017), and Gultom (2017) who concluded that marketing mix had an effect on tourists loyalty. Meanwhile, the results of the study by Al Muala and Al Qurneh (2012) concluded that products had a significant effect on touristsloyalty, while prices, people and processes had no significant effect on tourists loyalty. Esmaili et al. (2017) who concluded that prices, physical evidence and distribution had an effect on tourist loyalty.

\section{d) Service Quality Effects on Tourists Loyalty}

Based on the results of the study showed that service quality has a positive and significant effect on tourists loyalty in Samosir Region. The results of this study means that if the better implementation of service quality, it will increase tourists loyalty. Conversely, if the weak implementation of service quality, the tourists will be not loyal.

This research is in line with research conducted by Mohammed (2013), said that many organizations have realized that maintaining excellence depends on obtaining customer loyalty, because service quality is the material needed to convince customers to choose an organization than others.

Achieving a high level of quality service provided is the importance of loyal customers. Providing high-quality services is considered the most effective way to ensure the superiority of hospitality services over its competitors by maintaining customer loyalty. The results of this study reinforce the results of previous study conducted by Setiawan and Sayuti (2017), Azhar and Jufrizen (2017), Tefera and Govender (2017) who concluded that service quality had an effect on tourists loyalty. 
INDEPENDENT JOURNAL OF MANAGEMENT \& PRODUCTION (IJM\&P)

http://Www.ijmp.jor.br

V. 10, n. 5, September-October 2019

ISSN: 2236-269X

DOI: 10.14807/ijmp.v10i5.937

\section{e) Satisfaction Effects on Tourist Loyality}

Based on the results of the study showed that satisfactions had a positive and significant effect on tourists loyalty in Samosir Region. The results of this study means that if the better implementation of satisfactions, it will increase tourists loyalty. Conversely, if the weak implementation of satisfactions, the tourists will be not loyal. Bowen and Chen (2001) state that customer satisfaction is closely related to customer loyalty, where satisfied customers will become loyal customers.

Then the loyal customer will become a powerful marketing force for the company by providing recommendations and positive information to other prospective customers. The results of this study reinforce the results of previous study conducted by Setiawan and Sayuti (2017), Teviana et al. (2017), Azhar and Jufrizen (2017), Mohamad et al.. (2011), Tefera and Govender (2017), Suwunniponth (2013) and Gultom (2017) who concluded that tourist satisfactions had an effect on tourists loyalty.

- The Mediation Role of Tourist Satisfaction on the Effect of Marketing Mix and Service Quality on Tourist Loyalty. Based on the testing of mediation variables, it is evident that the tourist satisfaction variable acts as an intervening variable for the effect of exogenous variables on the marketing mix and service quality on tourist loyalty. The test results show that to increase tourist loyalty, the determining factor is tourist satisfaction, service quality and marketing mix. Loyal consumers are consumers who have a behavior that supports a company, have a commitment to buy back the company's products or services and recommend products or services to other parties so that it can be said to be an extraordinary marketing tool for the company. They can provide recommendations and spread word-of-mouth that are positive about the company, can increase sales by buying other products from the company and will buy these products more often and only require a smaller cost to satisfy them because they already know the product and requires less information about the product (BOWEN; CHEN, 2001). This is in accordance with the results of research conducted by Azhar anf Jufrizen (2017), and Gultom (2017), Al Muala and AI Qurneh (2012), Setiawan and Sayuti (2017), Tefera and Govender (2017), Teviana et al. (2017), Mohamad et al.. (2011) and Suwunniponth (2013). 
INDEPENDENT JOURNAL OF MANAGEMENT \& PRODUCTION (IJM\&P)

http://Www.ijmp.jor.br

V. 10, n. 5, September-October 2019

ISSN: 2236-269X

DOI: 10.14807/ijmp.v10i5.937

\section{CONCLUSION}

Based on data analysis and discussion, it can be concluded as follows: marketing mix had a positive and significant effect on tourist satisfactions in Samosir Region. Thus, the better implementation of marketing mix, then tourist satisfactions will be increased. Service quality had a positive and significant effect on tourist satisfactions of tourists in Samosir Region. Thus, the better service quality which perceived by tourists, then tourist satisfactions will be increased.

Marketing mix had a positive and significant effect on tourists loyalty in Samosir Region. Thus, the better implementation of marketing mix, then tourists loyalty will be higher. Service quality had a positive and significant effect on tourists loyalty in Samosir Region.

Thus, the better service quality which perceived by tourists, then tourist loyalty will be higher. Tourist satisfactions had a positive and significant effect on tourists loyalty in Samosir Region. Thus, the higher satisfactions which perceived by tourists, then their loyalties will be higher. Marketing mix and service quality had a significant effect on tourists loyalty in Samosir Region through the tourist satisfaction.

\section{SUGGESTIONS}

It was suggested to the tourism agents in Samosir Region to continue to maintain tourist satisfaction because it could provide benefits including reducing marketing costs, transaction costs, customer turnover costs, it could be increased cross selling so that the customer share becomes greater, reporting from mouth to mouth is more positive.

It is suggested to the related institutions to improve the service in the form of providing adequate public facilities so that tourists loyalty had more loyal in visiting tourism objects and the expected number of visitors would be increased. The next indicator could be expanded especially related to the marketing mix variables and service quality so it had better fit in the concept used.

\section{REFERENCES}

ADINEGARA, G. N. J.; SUPRAPTI, N. W. S.; YASA, N. N. K.; SUKAATMADJA, I. P. G, (2017) Factors That Influences Tourist's Satisfaction and Its Consequences, European Journal of Business and Management, v. 9, n. 8, p. 39-50. 
AL MUALA, A.; AL QURNEH, M. (2012) Assessing the Relationship between Marketing Mix and Loyalty through Tourists Satisfaction in Jordan Curative Tourism, American Academic \& Scholarly Research Journal, v. 4, n. 2.

AZHAR, M. E.; JUFRIZEN, (2017) The Analysis of The Tourist Loyalty Determinant In the Area of Toba Lake, International Journal of Recent Scientific Research, v. 8, n. 10 , p. $20826-20832$

BOWEN, J. T.; CHEN, S. L. (2001) The relationship between customer loyalty and customer satisfaction, International Journal of Contemporary Hospitality Management, v. 13, n. 5, p. 213-217

BUATON, K. W. S.; DAN PURWADIO, H. (2015) Kriteria Pengembangan Kawasan Wisata Danau Toba Parapat, Sumatera Utara, Jurnal Teknik ITS, v. 4, n. 1, p. C1C5

CANNON, J. P.; PERREAULT JR, W. D.; DAN MCCARTHY, J. (2008) Alih Bahasa: Diana Angelica dan Ria Cahyani. Pemasaran Dasar-Dasar: Pendekatan Manajerial Global. Buku 1 Edisi 16. Salemba Empat. Jakarta

DARYANTO. (2013) Sari Kuliah Manajemen Pemasaran. Bandung: Satu Nusa.

ESMAILI, S.; REZAEI, N.; ABBASI, R.; ESKANDARI, S. (2017) The Impact of Marketing Mix on Perceived Value, Destination Image and Loyalty of Tourists (Case Study: Khalkhal City, Iran), Modern Applied Science, v. 11, n. 11, p. 96-108. doi:10.5539/mas.v11n11p96

Giddens, N. (2002) Brand Loyalty and Decision Maker, lowa State University Extensions, v. 5, n. 54, p. 1-2.

GOVENDER, K. (2014) Journal Hotel Grading, Service Quality, Satisfaction and Loyalty Proposing a Theoretical Model and Relationship. Africa Journal of Hospitality, Tourism and Leisure in South Africa, n. 4.

GRIFFIN, J. (2005) Customer Loyalty, Menumbuhkan dan Mempertahankan Kesetiaan Pelanggan. Penerbit : Erlangga, Jakarta

GULTOM, D. K. (2017) Pengaruh bauran pemasaran jasa terhadap citra destinasi dan kepuasan wisatawan serta implikasinya terhadap loyalitas wisatawan. Jurnal Riset Sains Manajemen, v. 1, n. 2, p. 139-150 Retrieved from http://ejurnal.id/index.php/jsm/article/view/103

HADIYATI, E. (2012). Analisis Kualitas Pelayanan Dan Pengaruhnya Terhadap Loyalitas Pelanggan (Studi Kasus pada PT. Pos Indonesia (Persero) Kantor Pos Lawang). Jurnal Manajemen Fakultas Ekonomi Universitas Gajayana Malang HASAN, A. (2009) Marketing. Cetakan Pertama. Yogyakarta: Medpress.

HIDAYAT, N. C. (2010) Bauran Pemasaran Jasa Sebagai Alat Untuk Meningkatkan Potensi Pariwisata Di Kabupaten Banyuwangi, Jurnal IImiah PROGRESSIF, v. 7 , n. 9.

ISMAIL, M. B. M.; MUBARACK, K. M.; THULKIFLY, M. Z. (2015) Impact Of Service Marketing Mix On Customer Satisfaction, Journal of Management, v. 12, n. 2, p. 53-61

JOHNSON, M. D.; FORNELL, C. (1991) A Framework for Comparing Customer Satisfaction Across Individuals and Product Categories, Journal of Economic Psychology, v. 12, n. 2, p. 267-286 
INDEPENDENT JOURNAL OF MANAGEMENT \& PRODUCTION (IJM\&P)

http://Www.ijmp.jor.br

V. 10, n. 5, September-October 2019

ISSN: 2236-269X

DOI: 10.14807/ijmp.v10i5.937

KOTLER, P.; ARMSTRONG, G. (2009) Dasar- Dasar Pemasaran. Jakarta: $\mathrm{PT}$. Indeks.

KOTLER, P. (2009) Manajemen Pemasaran. Jilid I, Edisi Kesebalas, Jakarta : Indeks

KOTLER, P.; KELLER, K. L. (2009) Marketing Management. Upper Saddle River, NJ: Pearson Prentice Hall.

LAKSANA, F. (2008) Manajemen Pemasaran. Pendekatan Praktis. Edisi Pertama. Cetakan Pertama. Graha Ilmu. Yogyakarta.

LOVELOCK, C. H.; DAN WRIGHT, L. K. (2007) Manajemen Pemasaran Jasa. Jakarta Indeks.

LOVELOCK, C.; WIRTZ, J.; MUSSRY, J. (2011) Pemasaran Jasa. edisi 7. Jakarta : Erlangga

MEGATEF, S. G. (2015) The Impact of Tourism Marketing Mix Elements on the Satisfaction of Inbound Tourists to Jordan, International Journal of Business and Social Science, v. 6, n. 7, p. 41-58

MOHAMAD, M.; ALI, A. M.; GHANI, N. I. A. (2011) A Structural Model Of Destination Image, Tourists' Satisfaction And Destination Loyalty, International Journal Of Business And Management Studies, v. 3, n. 2, p. 167-177

MOHAMMED. G. (2013) Journal The Impact of Service Quality on Customers Loyalty A Study on Five Stars Hotel's Customers in Riyadh. Jurnal Administrasi Bisnis (JAB), v. 50, n. 5.

OLIVER, R. L. (2002) A cognitive model of the antecedents and consequencesof satisfaction decisions, Journal of Marketing Research, v. XVII, November.

OLSON, P. (1993) Consumer Behavior and Marketing Strategy, Richard D. Irwan Inc, Boston, Third Edition.

RASYID, M. J.; DANI, I.; ANDRIANI. B. (2017) The Effect Of Marketing Mix, Image And Service Quality Toward The Domestic Tourism Satisfactionin Bone District, Journal of Research in Business and Management, v. 5, n. 4, p. 69-73

RATNASARI, R. T.; DAN AKSA, M. (2011) Manajemen Pemasaran Jasa. Ghalia Indonesia. Bogor.

SETIAWAN, H.; SAYUTI, A. J. (2017) Effects of Service Quality, Customer Trust and Corporate Image on Customer Satisfaction and Loyalty: An Assessment of Travel Agencies Customer in South Sumatra Indonesia, IOSR Journal of Business and Management, v. 19, n. 5, p. 31-40

SIANTURI, T. (2004) Degradasi Danau Toba, Jurnal Penelitian Bidang IImu Pertanian, v. 2, n. 1, p. 1-3

SIMAMORA, B. (2008) Memenangkan Pasar Dengan Pemasaran Efektif dan

Profitable. Jakarta: PT. Gramedia Pustaka Utama.

SUWUNNIPONTH, W. (2013) Tourist Satisfaction and Loyalty toward Service Quality of the Online Tourism Enterprises, International Journal of Economics and Management Engineering, v. 7, n. 8, p. 2461-2462 
TEFERA, O.; GOEVENDER, K. (2017) Service quality, customer satisfaction and loyalty: The perceptions of Ethiopian hotel guests , Journal of Hospitality, Tourism and Leisure, v. 6, n. 2, p. 1-22

TEVIANA, T.; GINTING, P.; LUBIS, A, N.; GULTOM, P. (2017) Antecedents of Tourism Destination Image and Customer Satisfaction in Tourism Industry, European Research Studies Journal, v. XX, n. 3A, p. 435-445.

UNCLES, M. D.; DOWLING, G. R.; HAMMOND, K. (2003) Customer Loyalty and Customer Loyalty Programs, Journal of Consumer Marketing, v. 20, n. 4, p. 294316. doi:10.1108/07363760310483676

WELLS, W.; BURNETT, J.; MORIARTY. S. (2003) Advertising, Principles and Practice, sixth edition. New Jersey: Pearson Education, Inc.

YAMIT, Z. (2010) Manajemen Produk dan Jasa, Yogyakarta: Ekonisia YI, Y. (1991) A Critical Review of Consumer Satisfaction. In: Zeithmal, V. A. (ed.), Review of Marketing 1989. Chicago: American Marketing Association.

ZEITHMAL, V. A.; BERRY, L. L.; PARASURAMAN, A. (1996) The Behavioral Consequences of Service Quality. Journal of Marketing, v. 60, p. 31-46. 